Bull. Geol. Soc. Finland 42, 211-222 (1970)

\title{
PROTEROZOIC, ARCHEAM AND OTHER WEEDS IN THE PRECAMBRIAN ROCK GARDEN
}

\author{
Kalervo Rankama \\ Institute of Geology and Mineralogy, The University of Helsinki, Helsinki 17, Finland
}

\begin{abstract}
The use of the terms Precambrian; Proterozoic, Algonkian, and Archean; Cryptozoic and Archeozoic; and Eocambrian, Infracambrian, and Subcambrian is discussed. The Precambrian is no System in the sense of the Phanerozoic Systems but should be retained as the name of the longest recognized geochronologic unit and of the most extensive chronostratigraphic unit. A survey of literature and personal information received from Precambrian geologists in many parts of the world shows that the estimated age of the Proterozoic-Archean boundary ranges from about 3000 Ma to about $1700 \mathrm{Ma}$. The boundary is reasonably expected to be a worldwide isochronous boundary to which all Precambrian stratigraphers can return for reference. Unfortunately, it is not an isochronous boundary, and consensus as to its age seems to be impossible to reach. The Proterozoic and the Archean are recognized as valid terms only in their originally defined type areas. Their continued use as worldwide subdivisions of the Precambrian is not recommended. The other terms discussed are ill-defined, confusing, and meaningless. They should be discarded.
\end{abstract}

CONTENTS

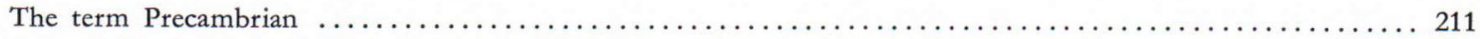

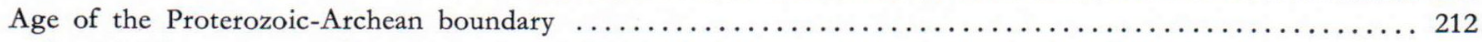

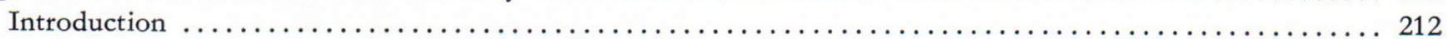

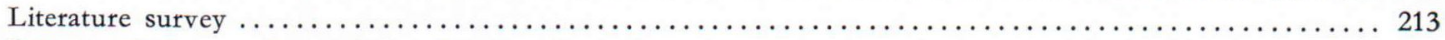

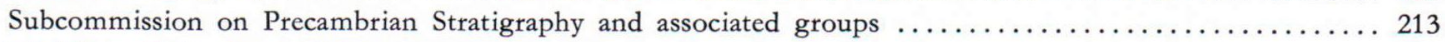

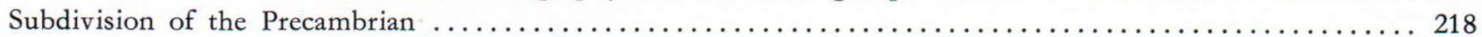

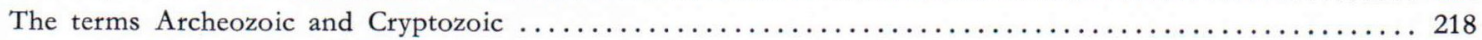

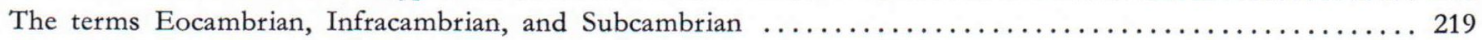

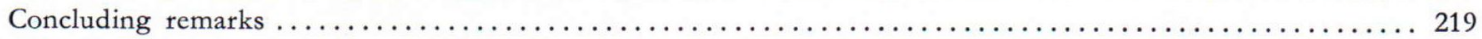

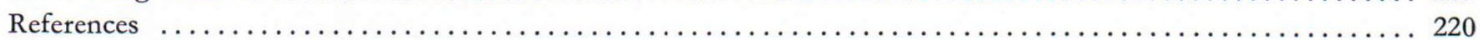

\section{The term Precambrian}

The Precambrian, according to its commonly accepted definition, comprises all rocks formed before Cambrian time. Some geochronologists, for instance, Wasserburg (1961, p. 583), have expressed the wish that this "unfortunate» name should be discarded altogether. Welin (1966, p. 32) wanted to retain the name for convenience. While Cloud (1968, p. 20) felt that the name is 
an anachronism he believed that it is a convenient single word for pre-Paleozoic (or pre-Phanerozoic) rocks and, furthermore, is currently being used.

At its meeting in Stockholm in 1969, the Subcommission on Precambrian Stratigraphy of the International Union of Geological Sciences passed unanimously the resolution that the Precambrian is no System in the sense of the Phanerozoic Systems. With this qualification, there is no objection to its continued use as the longest recognized geochronologic unit and as the most extensive chronostratigraphic unit.

\section{Age of the Proterozoic-Archean boundary}

\section{Introduction}

A report of the activities, in 1933, of the National Committee on Stratigraphical Nomenclature in Canada was published in 1934, written by F. J. Alcock (1934). As one would, perhaps naturally, expect, the subdivision of the Precambrian in the great Canadian Shield was the principal topic discussed by the Committee. Alcock (1934, p. 116) stated that, in the opinion of the Committee, the term Archean, being »such a fine word and so widely used", should be retained as one of the two major subdivisions (Eras) of the Precambrian. Proterozoic was recommended as the name of the other major subdivision. In general, the subdivision of the Precambrian resulted in ssuch a divergence of opinion on practically every point» that the agreement finally reached was the result of a general compromise (Alcock, 1934, p. 115).

The Precambrian stratigrapher of today reads about such past difficulties in a single country with interest and sympathy. The present-day situation relative to the worldwide subdivision of the Precambrian is very much similar, because Precambrian geologists are not used to think along global lines.

The introduction and history of the fine words Archean and Proterozoic have been discussed by
Wilson (1957), James (1958, 1960), Holmes (1963), and Eicher (1968), among others. A very brief outline is given in the following paragraphs.

The two terms were introduced in North America during the second half of the Nineteenth Century. In 1872, J. D. Dana used the term Archean for the whole Precambrian, but it has since been commonly accepted as the equivalent of Early Precambrian. Subsequently, in 1888, S. F. Emmons introduced the Era term Proterozoic for what is now called Late Precambrian. In 1889, the United States Geological Survey recognized a dual division of the prePaleozoic rocks. In this classification, the Archean was the basement complex of igneous and intensely deformed and metamorphosed crystalline rocks. The name Algonkian was used for postArchean Precambrian rocks, stated to be characterized by the absence of intense metamorphism and to be essentially of sedimentary origin. Consequently, the dual classification was based mainly on evidence of lithologic facies, extent of deformation, and degree of metamorphism. Dana used the name Archeozoic as the Era term corresponding to the Archean.

In 1906, T. C. Chamberlin and R. D. Salisbury presented the Algonkian-Archean classification in the form Proterozoic-Archeozoic. The name Algonkian fell gradually into disrepute in North America. Remarkably enough, it is still used in other parts of the world. For instance, Wurm (1964) used, for the subdivision of the Precambrian in Central Europe, a scheme that $\mathrm{H}$. Stille had devised in 1944, in which the Precambrian is divided into the Younger and the Older Algonkian and the Archean. I have listed other examples in another paper (Rankama, in press). The Algonkian certainly is a term that should be discarded.

The dual classification was originally used for the Lake Superior region in the Canadian Shield and has since been generally accepted as an authoritative standard and extended to Precambrian terranes in many parts of the world. It is deeply rooted but is certainly oversimplified 
and not acceptable. In addition, use of this fundamentally wrong classification with assumed time significance has resulted in endless confusion and in many entirely false conclusions and correlations. James (1960, p. 104) noted that the Proterozoic and the Archean, along with other familiar time terms and chronostratigraphic terms, are at least under attack except in their type areas, and Goldich (1968, p. 722) concluded that the Proteroic and the Archean (or the Archeozoic) have been used in many parts of the world for rocks that obviously are not of the same age. Consequently, the two names have outlived their usefulness. Holmes (1963, p. xix) commented on $»$ the tyranny of the Archaean correlation by a word of seemingly magic authority», a statement very much to the point that can equally well be extended to the Proterozoic.

The Geological Survey of Canada still retains the twofold classification and uses the Proterozoic and the Archean as Eon names, not as Era names, for the Precambrian of the Canadian Shield. However, as Holmes (1963, p. xx) remarked, the Proterozoic and the Archean, with ill-defined or overlapping boundaries, were useless terms from the start for correlation purposes, and meaningless in any time sense, and must remain meaningless until their time limits are defined. It is astonishing to note that, not long ago, the Precambrian chronostratigraphic units of the Lake Superior region were suggested to be used as tentative world standards in the subdivision of the Precambrian (Woodford, 1965, pp. $242-243$ ).

Considering the widespread use of the two old terms as major Precambrian subdivisions it is reasonable to expect that the ProterozoicArchean boundary would in fact be a worldwide isochronous marker, a fixed boundary to which all Precambrian stratigraphers can return for reference. Because it appeared that the age of the boundary has not received the attention that it definitely deserves, I decided to investigate it on the basis of a survey of published data. In addition, I decided to poll Members and several
Correspondents of the Subcommission on Precambrian Stratigraphy and Chairmen of the Precambrian Stratigraphy Groups in Denmark, Finland, Norway, and Sweden that report to the Subcommission. The results are presented and descussed in the following sections.

\section{Literature survey}

The results of the literature survey are presented in Table 1. No claim can be made as to completeness of literature coverage. Table 1 shows that the age values of the boundary fall within two groups, viz., a low-age group ranging from about $2100 \mathrm{Ma}$ to about $1700 \mathrm{Ma}$, and a high-age group ranging from about $3000 \mathrm{Ma}$ to about $2300 \mathrm{Ma}$. Most of the low-group ages have been proposed by Precambrian stratigraphers in the U.S.S.R. The high-group ages are mostly those proposed by stratigraphers in Canada, India, and Australia, with some found to be acceptable in the U.S.S.R. It is evident that no consensus exists as to the age of the boundary.

Subcommission on Precambrian Stratigraphy and associated groups

The age values of the Proterozoic-Archean boundary reported by Members and Correspondents of the Subcommission on Precambrian Stratigraphy and by Precambrian Stratigraphy Groups are listed in Table 2. I wish to extend my thanks to the persons who supplied information for their cooperation and kind permission to publish data incorporated in Table 2 and to quote from the documents made available to me. Several geologists supplying information incorporated in Table 2 discussed the situation in their respective countries and areas in amplifying comments. Such comments are digested, country by country, in the paragraphs to follow.

N orw a y. Tom. F. W. Barth remarked that the terms Proterozoic and Archean were used by geologists in Norway in the 1800's, while they 
are not used at all at present. He felt that a more detailed knowledge of the Precambrian of Norway is required before the terms may, eventually, be reintroduced.

TABLE 1

Age of the Proterozoic-Archean boundary. Values based on published information.

Age of boundary, Ma

(1) Low ages

(a) $1500-1000$;

(b) $1900-1800 \ldots$.

(a) 1700 ; (b) 1900

(likely value) $\ldots \ldots$....

$1900-1800 \ldots \ldots \ldots$

$1900 \pm 100 \ldots \ldots \ldots \ldots$

1900

$2000-1900 \ldots \ldots \ldots$

$1900 \pm 200 \ldots \ldots \ldots \ldots$

(2) High ages

About 2300 or older

(tentative) ..........

Approx. 2300 ......

2390

2400

2440

2450

2480

$2490 \ldots \ldots \ldots \ldots \ldots$

$2500 \ldots \ldots \ldots \ldots$

Approx. $2500 \ldots \ldots$....

$2500 \pm 100 \ldots \ldots \ldots \ldots$

$2500 \pm 150 \ldots \ldots \ldots \ldots$

$2600 \ldots \ldots \ldots \ldots \ldots$

$2600 \pm 100 \ldots \ldots \ldots \ldots$

$2700-2500 \ldots \ldots \ldots$

$2700-2600 \ldots \ldots \ldots$.

$2800-2600 \ldots \ldots \ldots$.

$3000-2300$ (broad ten-

tative range) .......
Gerling and Polkanov (1958)

Tamrazyan (1967)

Lazko (1964)

Dearnley (1965, 1966)

Vinogradov and Tugarinov (1961). J. Pereira and C. J. Dixon, quoted in Borchert (1968)

Obruchev (1964) ........

Sutton $(1967) \ldots \ldots \ldots \ldots$.

Dunn, Plumb, and Roberts (1966)

Dunn, Plumb, and Roberts (1967)

Stockwell (1963,1964a, 1965)

Woodford (1965). Stockwell (1968). Horwitz (1967a, 1968)

Anonymous (1966). Horwitz (1967b)

Stockwell (1964b). Bowes (1968)

Geological Survey of Canada (1969)

Stockwell (1967)

Stockwell (1961). Glaessner (1966). Naidenov and Cherdyntsev (1967). Sarkar (1968)

Cloud (1968)

Glaessner (1968)

Stockwell (1962)

Gerling, Kratz, and LobarZhuchenko (1968)

Semikhatov (1966)

Gerling and others (1965)

Choubert (1967). Ronov (1968)

Salop $(1964,1968)$

Leggo, Compston, and Trendall (1965)
East Africa and South-East Africa. Keith Bloomfield stated that the two terms have not been used very much in the past, mainly because of tectonic complexity that obscures true ages of deposition of strata.

France. G. Choubert reported that the term Proterozoic is not widely used.

A ustralia. P. R. Dunn wrote that, because the age limits of the Proterozoic-Archean boundary and the lithologic criteria are similar to those recognized for the boundary in Canada, Australian geologists have continued to use the two terms, even though some university circles claim that they are not valid in Australia. However, the Geological Survey of Western Australia uses the time classification of the Geological Survey of Canada (see Table 1). Incidentally, Dunn, Plumb, and Roberts (1967) proposed to retain the twofold subdivision, at least for the time being, but were looking forward to discontinuing the use of the two terms altogether.

C e ntral Africa. J. Lepersonne was not keen on using the two terms previously applied to distinguish among terranes with different degrees of metamorphism. He concluded that such differences are of no stratigraphic value and that the two terms have been used with different meanings in different countries, with ensuing confusion about their meaning. He felt that there is little hope about a unanimous decision as to the age of the boundary, especially because no suitable criterion can be devised for the subdivision of the Precambrian into two major units. The two terms, in his opinion, are useless.

Great B rit a i n. W. B. Harland indicated that, if compelled to define the age of the boundary, he would be inclined to seek a round figure, and suggested $2500 \mathrm{Ma}$ as the age. In his opinion, the terms Proterozoic and Archean, if stand. ardized, would be more appropriate to the strati graphic scale than to the geochronologic scale.

U. S. A. The situation has changed very much since the introduction and early use of the two 
terms. Harold L. James stated that the terms are no longer used by the U.S. Geological Survey, have largely disappeared from geologic literature since about 1950 , and are not formally recognized (see also James, 1958, p. 29). If used at all, they bear no explicit definition. The names Late Precambrian and Early Precambrian are recommended for the two major divisions of Precambrian time. The dominant view is that the terms Proterozoic and Archean should be abandoned. Nevertheless, there still exists a minority reluctant to abandon these familiar terms and preferring their redefinition.

G r e e $\mathrm{n} l$ a n d. Arne Noe-Nygaard reported that the term Proterozoic has never been used in published reports written by geologists who have personally carried out field work in Greenland. The term Archean has been generally used in papers published before the introduction of radiometric dating. The term Algonkian, referring to various parts of the Precambrian, has also been in use. The Danish Precambrian Stratigraphy Group assumes that, even if the two names are dropped, the Proterozoic-Archean boundary is intended to be the major division of Precambrian time. It may be based on various criteria, among which the Group prefers a geologic feature as the only stable criterion.

In di a. According to S. N. Sarkar, the currently used chronostratigraphic classification of the Precambrian of the Canadian Shield is the most suitable one for India and affords complete correlation.

Fin land. Ahti Simonen noted that the terms Proterozoic and Archean have not been commonly used.

Ca na da. Still in 1957, the Geological Survey of Canada recognized the uncertainty as to the exact position of the Proterozoic-Archean boundary (J. M. Harrison, quoted in James, 1958 , p. 29). Nowadays, Canadian geologists, following C. H. Stockwell (1961, 1962, 1964a, 1968) consider the Proterozoic and the Archean large first-order units of Eon rank, useful for permitting a gross time classification in the $\mathrm{Ca}$ nadian Shield, and, for several reasons, place the Proterozoic-Archean boundary at the close of the Kenoran orogeny in its type region, the Superior province of the Canadian Shield. The boundary, the age of which is given with a remarkable accuracy (see Table 2), is a natural boundary, the most fundamental and widespread stratigraphic boundary in the Shield, and marks, in Canada at least, a basic change in many geologic features. Stockwell further concluded that the boundary chosen seems to form a natural, mappable, boundary in many, if not most, countries. He also regretted the use of the terms Proterozoic and Archean with a different meaning in some papers published after their formal definition about 35 years ago.

U. S. S. R. According to A. I. Tugarinov, the Proterozoic-Archean boundary marks the start of large-scale surface oxidation, caused by the change from a reducing atmosphere to an oxidizing one, and consequently is also the boundary of one of the greatest geologic changes in the history of the Earth. His opinion largely reflects the belief of Ronov (1968, p. 41) who thought that the boundary marks an epoch of abrupt change in the history of the uppermost geospheres.

Southern Africa. John de Villiers wrote that it is important to take the craton development in the subcontinent into consideration. Consequently, the logical position at which to place the Proterozoic-Archeozoic (Archean) boundary is the time at which the craton, or a very stable Shield nucleus, was finally established in Swaziland and in the eastern Transvaal.

$\mathrm{S} w$ e d e n. Reporting for the Precambrian Stratigraphy Group of Sweden, Eric Welin stated that the term Algonkian has never been widely used and should be abandoned. The Group feels that the Proterozoic and the Archean are acceptable as stratigraphic subdivisions of the Precambrian, even though their boundary 
TABLE 2

Age of the Proterozoic-Archean boundary. Values based on personal information.

Country (Continent)

Age of boundary, Ma

Information supplied by

\author{
Tom. F. W. Barth (1968) \\ Keith Bloomfield (1969) \\ Ditto \\ Ditto \\ Ditto \\ Ditto \\ Georges Choubert (1968) \\ P. R. Dunn (1968) \\ Ditto \\ Reinholt Ellert (1969) \\ W. B. Harland (1968) \\ J. Lepersonne (1968) \\ Arne Noe-Nygaard (1969) \\ S. N. Sarkar (1968) \\ Ahti Simonen (1968) \\ C. H. Stockwell $(1968,1969)$ \\ A. I. Tugarinov (1968) \\ John de Villiers (1968) \\ Eric Welin (1969) \\ Raúl A. Zardini (1969) \\ V. Zoubek (1968)
}

2500

about 2500 , but terms generally no

longer formally used and recognized

Establisment of boundary considered impossible

Not defined

India $\ldots \ldots \ldots \ldots \ldots \ldots \ldots$ about 2500

Finland ................. Boundary assumed to lie between 2600

$\mathrm{Ma}$ and $1900 \mathrm{Ma}$; exact age unknown

$2450+30$

$2600 \pm 100$

$2900 \pm 100$

Boundary not defined

Terms not in use

2 500; Archean absent has not been defined in a precise manner. The Group, however, is not prepared to recommend an age for the boundary. Geologists in Sweden are inclined not to use the three terms, because they have not been adequately defined.

A rgentina. Raúl A. Zardini reported that the terms Proterozoic and Archeozoic (Archean) are not used in the stratigraphic subdivision of the Precambrian.

Table 2 shows that not even the specialists agree as to the age of the Proterozoic-Archean boundary. The material supplied by them is, in fact, utterly confusing. The age values, mostly based on perfectly good and valid arguments, range from about $3000 \mathrm{Ma}$ to about $1700 \mathrm{Ma}$ indicating that the boundary certainly not is a worldwide isochronous boundary. Several geologists report that the terms Proterozoic and Archean are not used at all in their countries or that the determination of the age of the boundary is not considered possible. Incidentally, Wilson
(1957, p. 15) considered placing the boundary at some arbitrary date, e.g., $1 \mathrm{Ga}$ ago, but felt that this procedure had little to recommend it.

A reasonable conclusion drawn from data given in Tables 1 and 2 is that opinions as to the age of the boundary differ widely. The Subcommission on Precambrian Stratigraphy, at its meeting in Prague in 1968, discussed this problem very briefly, but no consensus was reached, and, unfortunately, only four Members were able to attend the meeting. Similarly, at its meeting in 1969, the Subcommission was planning to discuss the subdivision of Precambrian time. However, it soon became evident that those present were thinking along regional and subcontinental lines, rather than along global lines. Consequently, a comprehensive and fruitful discussion was considered impossible at that time.

The extensive age spread evident from Tables 1 and 2 clearly shows that the ProterozoicArchean boundary is not an isochronous boundary. Consensus as to its age seems to be impossi 
ble to reach, even though it would be urgently needed, as Glaessner (1967), among others, has emphasized. The original meanings of the names Proterozoic and Archean have been modified since they were first used. Precambrian stratigraphers use them today with different meanings. They mean different things in different parts of the world. What is called Archean in one country may be largely Proterozoic in another country. The two terms have caused, and if continued in use will cause, endless confusion.

My conclusion, then, is that the Proterozoic and the Archean are meaningful and valid terms only in their originally defined type areas in the Lake Superior region in Ncrth America. Their continued use as worldwide subdivisions of the Precambrian cannot be recommended. They have lost their meaning in present-day global Precambrian chronostratigraphy and as global geochronologic units and are terms to be discredited, now living on borrowed time. This conclusion, of course, represents my personal views and does not bind the Subcommission on Precambrian Stratigraphy. In reaching the conclusion that the two terms are to be discredited, I know that I must be treading on somebody's toes and am afraid that hard feelings will be engendered. However, after a careful examination of the prevailing situation, I conclude that radical departure from established custom is necessary.

It follows that the terms Eparchean and Eparchean unconformity have no validity. Similarly, the term Katarchean must be discarded as another ill-defined term, as must the Eoarchean that Nieuwenkamp (1965, p. 470) defined as the time during which the oldest rocks so far discovered were formed, that is, the time $3 \mathrm{Ga}-$ $4 \mathrm{Ga}$ ago.

Several geologists have previously condemned the Proterozoic and the Archean as inappropriate terms. Gill (1955, p. 25) concluded that they should be dropped, because they are not needed, or else should be used exclusively in a time sense. He considered the Early Precambrian and the
Late Precambrian sufficient as time terms but noted that they should be used only when geochronometric evidence is adequate. Wilson (1957, pp. 10-17) concluded that geologists have never agreed as to the precise meaning of the two terms. If used at all, they should not be used as time terms, because they imply certain types of rocks. The term Archean has been considerably restricted and abused, and its continuing use can be justified, in his opinion, on historical grounds, for the oldest predominantly volcanic rocks and associated igneous rocks. The use of the term Proterozoic for the rest of Precambrian time requires much greater distortion and is less justified, because its original meaning has changed much and because it has been used for a great »variety of concepts». Holmes (1963, p. xix) quoted several examples showing how meaningless, and yet how persistent, the term Archean has become. Admitting that the twofold subdivision of the Precambrian has encountered difficulties and is hardly possible, Woodford (1965, p. 223) concluded that the terms Proterozoic and Archean, and Archeozoic, have become useless. Dearnley (1966, p. 4) also found that the two broad terms have lost their original meanings. Consequently, they should be redefined on a worldwide basis, if they are to remain useful. Trendall (1966, p. 522) agreed that the term Proterozoic has been rendered completely meaningless by a proliferation of meanings and that international agreement on a single meaning is not possible. Harland (1968, p. 262) noted that time terms like the Proterozoic have been used in a general sense, unrelated even to animal life. However, Glaessner (1967) stood up for the Proterozoic, feeling that international agreement on its meaning would not be impossible, unless it is divorced from rocks, in which case it will have no meaning.

It is appropriate to consider here the basic difference between chronostratigraphic units and geochronologic units. Chronostratigraphic units are material units bound to certain rock sequences or rock sections. If divorced from rocks, they 
are meaningless. Geochronologic units, or units of geologic time, are not material units and are not connected with any particular rocks.

\section{Subdivision of the Precambrian}

What is there to replace the old twofold subdivision of the Precambrian? Various schemes have been proposed, some of which I have discussed in another paper (Rankama, in press). In northern Michigan in the U.S.A., James (1958, p. 27) used a threefold subdivision into the Lower, the Middle, and the Upper Precambrian. These groups have later been used informally in a time sense. Woodford (1965, p. 242) suggested a tentative worldwide fourfold division based on the chronostratigraphic units of the Lake Superior region in North America. Similarly, Goldich (1968, p. 722) proposed a threefold global classification into the Early, the Middle, and the Late Precambrian, with time boundaries adopted from the Lake Superior region.

Other general subdivisions have been proposed, with boundaries established according to metamorphic and plutonic events. Sutton (1967, p. 501) adopted tentative subdivisions called Precambrian I (oldest), II, III, and IV, based on chelogenic, or shieldmaking, cycles. Vinogradov and Tugarinov (1968, p. 48) proposed a threefold subdivision into the Lower, the Middle, and the Upper Precambrian on the basis of tectonicmagmatic epochs. Lotze (1968, p. 665) subdivided the Precambrian into six standard units, Precambrian A (oldest) through $\mathrm{F}$, with age boundaries placed arbitrarily at $500 \mathrm{Ma}$ intervals.

Entirely different views have also been presented and endorsed. Trendall (1966, p. 521) suggested that, instead of splitting Precambrian time into named divisions of various lengths, either the name Precambrian or a numerical expression of age should be used, as appropriate. Harold L. James (personal communication, 1969) reported that, in the U.S.A., some geologists at least have advocated the view that Precambrian time should be subdivided on a simple numerical basis (1000 Ma, $1500 \mathrm{Ma}, 2000 \mathrm{Ma}$, etc.), without regard for geologic events, such as orogenies.

The British National Committee for Geology (1968, p. 23) stated that divisions of the Precambrian desirable for immediate international use should be based on ages in years and, if named, should be named independently of concepts concerning the history of the Earth or geography, in order to avoid confusion with the Standard Stratigraphic Scale.

This review shows that there exists no generally adopted subdivision of Precambrian time. The various schemes of subdivision that have been presented differ from one another enough not to be accepted by all Precambrian geologists and stratigraphers. As a temporary solution, I suggest the use of only the name Precambrian, followed by an age in $\mathrm{Ma}$ or $\mathrm{Ga}$ in parentheses. Thus, Precambrian (680 Ma), Precambrian (1.7 Ga-1.6 Ga), etc. I see no possibility of using the terms the Early, the Middle, and the Late Precambrian, because they have not been adequately defined and because there is no consensus as to their age boundaries. However, the Early Precambrian and the Late Precambrian may be useful as general terms of convenience.

\section{The terms Archeozoic and Cryptozoic}

An Era is a unit of geologic time that corresponds to a broad phase in the development of terrestrial life. Hence, the Cenozoic, the Mesozoic, the Paleozoic, the Proterozoic, and the Archeozoic Eras have been introduced and used (see Hedberg, 1961, p. 27). Glaessner (1966, p. 35) wanted to exclude the name Archeozoic, not because of its meaning, but because it is rarely used. Considering the present-day knowledge of life early during the Precambrian, Archeozoic is no more an appropriate term unless it is redefined to mean that part of Precambrian time during which life has existed on the Earth, in other 
words, the span of time from the appearance of the earliest life to the close of the Precambrian.

The term Cryptozoic Eon has been used as a geochronologic unit as the equivalent of the Precambrian. Basically, two great geochronologic divisions, viz., the Phanerozoic Eon and the Cryptozoic Eon, have been acknowledged. The Phanerozoic Eon consists of the Cenozoic, the Mesozoic, and the Paleozoic Eras. It is customarily claimed that, contrary to the Phanerozoic Eon, the Cryptozoic Eon witnesses of only relatively scanty life, mostly simple and primitive forms. Cloud (1968, p. 20) felt that the name Cryptozoic applies logically only to $n$ the younger Precambrian" but that, by retaining the contrasting terms Phanerozoic and Cryptozoic it is useful to refer to the two great divisions of geologic time.

While the Cryptozoic, according to its original definition, is the Eon of hidden life, the results of present-day Precambrian paleontology show that the evidence of Precambrian life in rocks is largely manifest rather than concealed. It appears that, like the Archeozoic, the Cryptozoic is an ill-defined and confusing term not suitable for use. Consequently, the Subcommission on Precambrian Stratigraphy at its meeting in 1969 unanimously recommended that the two terms be dropped as meaningless.

\section{The terms Eocambrian, Infracambrian, and Subcambrian}

There exist three elusive stratigraphic terms, derived from the term Cambrian and uncomfortably straddling the boundary between the Cambrian and the Precambrian. The Eocambrian is one of these ill-defined units. Traves (1957, p. 78) used the Eocambrian as equivalent to the Upper Proterozoic. According to Magnusson (1965, pp. 1-2), Eocambrian, or the uppermost Precambrian, in Sweden consists of the topmost sedimentary-rock strata underlying the so-called Subcambrian peneplain. Holmes (1959, p. 192) said that ill-defined terms like the Eocambrian are confusing because they appear to extend the Paleozoic downward and because they suggest the possibility of worldwide time correlation that cannot as yet be justified. Similarly, Harland (1964, p. 126) listed a number of points against the use of the Eocambrian, preferring to use instead the term Infracambrian that extends from the onset of the great Infracambrian glaciation to a time before the appearance of recognized basal Cambrian faunas. However, the term Infracambrian that P. Pruvost in France introduced in 1951, is a very inadequately defined unit, use by most French-speaking geologists as a synonym of the Upper Precambrian and largely ignored by English-speaking geologists (Choubert, 1963 , p. 94; 1967 , p. 129). Because the Infracambrian was originally an ill-defined term and because it has been used by various geologists with different meanings, it has created misunderstandings and problems and should be discarded (Georges Choubert, personal communication, 1968). Finally, the term Subcambrian has been sometimes used to denote uppermost Precambrian strata (see, e.g., Noakes, 1957, p. 214), but it has never gained general acceptance and is illdefined.

At its meeting in 1969, the Subcommission on Precambrian Stratigraphy considered the three terms and unanimously concluded that the Eocambrian, the Infracambrian, and the Subcambrian, being ill-defined, confusing, and meaningless, should be dropped. The tentative term, Uppermost Precambrian, plus an age in parentheses, was recommended to be used instead of the discredited terms, e.g., Uppermost Precambrian (610 Ma).

\section{Concluding remarks}

I have now reached the end of this discourse. My study of growth in the Precambrian rock garden shows that, unfortunately, all too many geosemantic weeds grow there. The garden certainly needs thorough weeding. 
Global Precambrian stratigraphy still has a long way to go before a subdivision acceptable to everybody concerned has been introduced and an international agreement has been reached. This is a tall order. However, one agrees with Moody (1966, p. 8) who said that when existing terms don't fit situations, new terms should be coined, when necessary, and as a last resort. This is preferable to indiscriminately altering the meaning of established terms.

It is time to get serious, rather than to continue playing with stratigraphic terms. It is encouraging to note the interest in all aspects of the
Precambrian that has grown so rapidly during the past few years and has produced a vast store of new pertinent information. The special and all-pervading difficulty inherent in the Precambrian, however, is the mind-boggling length of Precambrian time that almost defies understanding. Still, all Precambrian time is only a drop in the bucket of Time. »Nothing is so plentiful as Time».

Acknowledgment. - This investigation was supported by research grants from Academia Scientiarum Fennica and Societas Scientiarum Fennica. These subsidies are gratefully acknowledged.

\section{REFERENCES}

Alсоск, F. J. (1934) Report of the National Committee on Stratigraphical Nomenclature. Trans. Roy. Soc. Can., Sect. 4, 28, 113.

Anonymous (1966) Provisional subdivisions of the Precambrian in Western Australia 1966. Geol. Surv. Western Australia, Ann. Rept. for 1965, 46.

Borchert, H. (1968) Lagerstätten und Computer. Mitteilungsbl. Tech. Univ. Clausthal Nr. 17, 19.

Bowes, D. R. (1968) The absolute time scale and the subdivision of Precambrian rocks in Scotland. Geol. Fören. Stockholm Förh. 90, 175.

British National Committee for Geology (1968) International Geological Correlation Programme. United Kingdom Contribution. London.

Choubert, G. (1963) Histoire géologique du Précambrien de l'Anti-Atlas. Maroc, Notes Mém. Serv. Géol. No. 162.

Choubert, Georges (1967) Divisions du Précambrien, en particulier dans l'Anti-Atlas. Compt.rend. Soc. géol. France No. 4, 129.

Cloud, Jr., Preston E. (1968) Pre-metazoan evolution and the origins of the Metazoa. In: Evolution and Environment (Ellen T. Drake, Ed.), 1. New Haven.

Dearnley, R. (1965) Orogenic fold belts and continental drift. Nature 206, 1083.

- (1966) Orogenic fold-belts and a hypothesis of Earth evolution. Phys. Chem. Earth 7, 1.

Dunn, P. R., Plumb, K. A., and Roberts, H. G. (1966) A proposal for time-stratigraphic subdivision of the Australian Precambrian. J. Geol. Soc. Australia 13, 593.
- (1967) A proposal for time-stratigraphic subdivision of the Australian Precambrian. ANZAAS Congr. Melbourne, Sect. C, Abstracts, Jan., 1967, I 8.

Ercher, Don L. (1968) Geologic Time, 64. Englewood Cliff, N. J.

Geological Survey of Canada (1969) Tectonic map of Canada. Map 1251 A. Prepared by the Tectonic Map of Canada Committee (C. H. Stockwell, Chairman).

Gerling, E. K., Glebova-Kulbakh, G. O., LobachZhuchenko, S. B., Afanaseva, L. I., and Vasileva, S. N. (1965) Novye dannye po geokhronologii Dokembriya Karelii. In: Akad. Nauk. SSSR, Lab. Geol. Dokembriya, Absolyutnyi Vozrast Dokembriiskikh Porod SSSR, 35.

- Kratz, K., and Lobach-Zhuchenko, S. (1968) Precambrian geochronology of the Baltic Shield. Intern. Geol. Congr., Rept. 23rd Session, Czechoslovakia 1968, Proc. Sect. 4, 265.

- and Polkanov, A. A. (1958) The absolute age determination of the Precambrian of the Baltic Shield. Geochemistry (U.S.S.R.), English Transl. no. 8, 867.

GILl, J. E. (1955) Precambrian nomenclature in Canada. Trans. Roy. Soc. Can., Sect. 4, 49, 25.

Glaessner, M. F. (1966) Precambrian palaeontology. Earth-Sci. Rev. 1, 29.

- (1967) Current discussions on the basic principles of Precambrian time-scales. IUGS-Commission on Geochronology. Mimeographed report.

- (1968) Biological events and the Precambrian time scale. Can. J. Earth Sci. 5, 585. 
Goldich, S. S. (1968) Geochronology of the Lake Superior region. Can. J. Earth Sci. 5, 715.

Harland, W. B. (1964) Evidence of Late Precambrian glaciation and its significance. In: Problems in Palaeoclimatology (A. E. M. Nairn, Ed.), 119. New York.

- (1968) On the principle of a Late Pre-Cambrian stratigraphical standard scale. Intern. Geol. Congr., Rept. 23rd Session, Czechoslovakia, Proc. Sect. 4, 253.

Hedber G, Hollis D. [Editor] (1961) Stratigraphic classification and terminology. Intern. Geol. Congr., Rept. 21st Session, Norden. Part 25.

Holmes, Arthur (1959) A revised geological time-scale. Trans. Edinburgh Geol. Soc. 17, pt. 3, 183.

- (1963) Introduction. In: The Precambrian (Kalervo Rankama, Ed.), vol. 1, xi. New York.

Horwrtz, R. C. (1967a) Provisional subdivisions of the Precambrian in Western Australia, 1966. Geol. Surv. Western Australia, Ann. Rept. for 1966, 58.

- (1967b) Pangaea and some units in the Precambrian and the Palaeozoic. Tectonophys. 4, 5.

- (1968) Provisional subdivisions of the Precambrian in Western Australia, 1967. Geol. Surv. Western Australia, Ann. Rept. for 1967, 44.

James, Harol d L. (1958) Stratigraphy of pre-Keweenawan rocks in parts of northern Michigan. U.S. Geol. Surv. Profess. Paper 314-C, 25.

- (1960) Problems of stratigraphy and correlation of Precambrian rocks with particular reference to the Lake Superior region. Am. J. Sci. 258-A (Bradley Vol.), 104.

LAzко, E. M. (1964) K kharakteristike Arkheiskogo i Proterozoiskogo etapov $\mathrm{v}$ istorii Zemnoi kory na primere Dokembriiskikh kompleksov Evrazii. Mezhdunarodnyi Geol. Kongress, 22 Sessiya, Doklady Sovetskikh Geologov, Problema 10, Geologiya Dokembriya, 31. Moscow.

Leggo, P. J., Compston, W., and Trendall, A. F. (1965) Radiometric ages of some Precambrian rocks from the northwest division of Western Australia. J. Geol. Soc. Australia 12, 53.

Lotze, Franz (1968) Vergleichende Betrachtung des Präkambriums der Gesamterde. In: Handbuch der Stratigraphischen Geologie, Bd. 13, Präkambrium, II. Teil (Fr. Lotze, Ed.), 642. Stuttgart.

Magnusson, Nils H. (1965) The Pre-Cambrian history of Sweden (Eighteenth William Smith Lecture). Quart. J. Geol. Soc. London 121, 1.

Moody, J. D. (1966) Geosemantics. Geotimes 11, no. 2, 8.

Naidenov, B. M. and Cherdyntsev, V. V. (1967) The evolution of the Earth's crust according to data on isotopic composition of ore lead (Russian). Dokl. Akad. Nauk SSSR 172, 688. According to abstract in Chemical Abstracts 66, Abstr. No. 87,633t. 1967.
Nieuwenkamp, W. (1965) Geschichtliche Entwicklung der heutigen petrogenetischen Vorstellungen. Geol. Rundschau 55, 460.

Noakes, L. C. (1957) Upper Proterozoic and Sub-Cambrian rocks in Australia. In: The Cambrian geology of Australia (A. A. Öpik, Ed.). Bur. Mineral Resources, Geol. Geophys., Bull. 49, 213.

Oвruchev, S. V. (1964) Osnovnye podrazdeleniya Proterozoya v SSSR. Mezhdunarodnyi Geol. Kongress, 22 Sessiya, Doklady Sovetskikh Geologov, Problema 10, Geologiya Dokembriya, 9. Moscow.

Rankama, Kalervo (In press): Global Precambrian stratigraphy: background and principles.

Ronov, A. B. (1968) Probable changes in the composition of sea water during the course of geological time. Sedimentology 10, 25.

SALOP, L. I. (1964) Geokhronologiya Dokembriya i nekotorye osobennosti rannego etapa geologicheskogo razvitiya Zemli. Mezhdunarodnyi Geol. Kongress, 22 Sessiya, Doklady Sovetskikh Geologov, Problema 10, Geologiya Dokembriya, 16. Moscow.

- (1968) Pre-Cambrian of the U.S.S.R. Intern. Geol. Congr., Rept. 23rd Session, Czechoslovakia 1968, Proc. Sect. 4, 61.

SARkar, S. N. (1968) Pre-Cambrian stratigraphy and geochronology of Peninsular India. Dhanbad.

Semikнатоv, M. A. (1966) K probleme stratigraficheskoi skhemy Dokembriya. Izv. Akad. Nauk SSSR, Ser. Geol., No. 4, 70.

Stockwell, C. H. (1961) Structural provinces, orogenies, and time classification of rocks of the Canadian Precambrian Shield. In: Age determinations by the Geological Survey of Canada. Geol. Surv. Can., Paper $61-17,108$.

- (1962) A tectonic map of the Canadian Shield. In: The tectonics of the Canadian Shield. Roy. Soc. Can., Spec. Publ. No. 4, 6.

- (1963) Second report on structural provinces, orogenies, and time-classification of rocks of the Canadian Precambrian Shield. In: Age determinations and geological studies. Geol. Surv. Can., Paper 62$17,123$.

- (1964a) Fourth report on structural provinces, orogenies, and time-classification of rocks of the Canadian Precambrian Shield. In: Age determinations and geological studies. Part II. Geological studies. Geol. Surv. Can., Paper 64-17 (Part II), 1.

- (1964b) Principles of time-stratigraphic classification in the Precambrian. In: Geochronology in Canada. Roy. Soc. Can., Spec. Publ. No. 8, 52.

- (1965) Structural trends in Canadian Shield. Bull. Am. Assoc. Petrol. Geologists 49, 887.

- (1967) Geochronology of stratified rocks of the Canadian Shield (Abstract). Geochronology of Precam- 
brian Stratified Rocks, Dept. Geol., Univ. Alberta, Edmonton, Can., June 1967, Abstracts of papers, 89.

- (1968) Geochronology of stratified rocks of the Canadian Shield. Can. J. Earth Sci. 5, 693.

Sutton, John (1967) The extension of the geological record into the Pre-Cambrian. Proc. Geologists' Assoc. Engl. 78, 493.

Tamrazyan, G. P. (1967) The global historical and geological regularities of the Earth's development as a reflection of its cosmic origin (as a sequence of interaction in the course of Galactic movement in the Solar System). Sb. věd. prací Vysoké školy báňské Ostravě, Ročník 13, 1967, řada hornicko-geologická 182, 5 (Published in 1968).

Traves, D. M. (1957) Upper Proterozoic and Cambrian geology in northwestern Australia. In: The Cambrian geology of Australia (A. A. Öpik, Ed.). Bur. Mineral Resources, Geol. Geophys. Bull. 49, 75.

Trendall, A. F. (1966) Towards rationalism in Precambrian stratigraphy. J. Geol. Soc. Australia 13, 517. Vinogradov, A. P. and Tugarinov, A. I. (1961) Geo- chronology of the Precambrian. Geochemistry (U.S.S.R.), English Transl. No. 9, 787.

- - (1968) Geokhronologicheskaya shkala Dokembriya. Mezhdunarodnyi Geol. Kongress, 23 Sessiya, 1968. Doklady Sovetskikh Geologov, Problemy 6 i 13a, 47. Moscow.

Wasserbur G, G. J. (1961) Crustal history and the PreCambrian time scale. Ann. N.Y. Acad. Sci. 91, 583.

Welin, Eric (1966) The absolute time scale and the classification of Precambrian rocks. Geol. Fören. Stockholm Förh. 88, 29.

Wilson, J. T. (1957) Discussion of "Proterozoic in Canada». Roy. Soc. Can., Spec. Publ. 2, 10.

Woodford, A. O. (1965) Historical geology. San Francisco and London.

Wurm, A. (1964) Über den Stand der erdgeschichtlichen Forschung im Kristallin des Moldanubikums und Saxothuringikums Mitteleuropas. Neues Jahrb. Paläontol., Monatsh., H. 2, 65.

Manuscript received January 25, 1970. 